\title{
Development of Pastry Formulas with High Antioxidant Content
}

\author{
Assiya Abushaeva*, Madina Sadigova, Angela Kondrashova
}

Saratov State Agrarian University named after N.I. Vavilov, 410005, Saratov, Sokolovaya, 335 , Russian Federation

\begin{abstract}
The article presents the results of a study of the effect of prescription components on the antioxidant activity of flour confectionery products. The main raw material used was light grain rye flour of the Saratov selection of the varieties Solnyshko and Pamyati Bambysheva. Vegetable powders from carrots and beets, as well as jam and candied carrots were used as vegetable components. Phenolic compounds contained in flour from light-grain rye and processed vegetables from carrots and beets have extensive biological functions and have a beneficial effect on living organisms, which makes their research relevant. The measurements are carried out on the analyzer of antioxidant activity TsvetYauza-01-AA in comparison of the received signal with the signal of the quercetin standard. In experimental samples of flour confectionery products based on wheat flour with vegetable processing products, the content of antioxidants increases 2.4 times, compared with the control sample. Whereas in experimental samples of flour confectionery products based on flour from light grain rye, the content of antioxidants increases 34 times, compared with the control sample from wheat flour. However, when comparing control samples in a sample based on flour from the grain of light grain rye variety Solnyshko, the content of antioxidants is 1.8 times higher, in contrast to the sample from wheat flour.
\end{abstract}

\section{Introduction}

Currently, according to the concept of the national technological initiative, the food industry until 2035 is tasked with creating, producing and selling personalized and general, based on traditional raw materials and their substitutes, food products, using health-saving technologies, taking into account diseases, food allergies, types professional activity, national traditions, and etc. [1].

Due to the deterioration of the ecological state of the environment, changes in the nature of nutrition, the development of food technology, which involves the use of a large number of food additives, including synthetic origin, the antioxidant balance of the human body is disrupted, which leads to an increase in the number of free radicals. Free radicals are the cause of many diseases, namely, such as: diabetes mellitus, chronic nonspecific lung

\footnotetext{
${ }^{*}$ Corresponding author: asiyatugush@mail.ru
} 
diseases, diseases of the reproductive system, radiation injury, hepatitis, decreased cellular and humoral immunity, intoxication with membrane poisons, and etc. [2].

Own antioxidants are not enough to fight the increased number of free radicals; therefore, the introduction of additional antioxidants with food contributes to an increase in the antioxidant status of the body.

Antioxidants are natural or synthetic substances that are able to slow down or stop oxidation; it is an important indicator that is associated with the spread of oxidative processes and their negative consequences in any field of activity. The value of antioxidants in the food industry is associated with: 1) an increase in the antioxidant status of the body; 2 ) improving the quality and terms of storage of food products, in particular fat-containing [3].

Oxidative processes that take place in flour confectioneries reduce their nutritional value, consumer qualities and shelf life. They are the reason for the putrid smell of an expired product or the rancidity of fats in flour confectionery products.

Currently, much attention is paid to the use of natural antioxidants. These include vitamins $\mathrm{C}, \mathrm{A}, \mathrm{K}, \mathrm{PP}$, beta-carotene and vitamin $\mathrm{E}$ and its derivatives, essential oils, phenolic compounds, as well as the minerals selenium, zinc and sulfur contained in light rye grain flour, in vegetable powders from the roots of carrots and beets, as well as candied fruits and carrot jam [4].

The biological activity of naturally occurring phenolic compounds is associated with their antioxidant properties. Phenolic compounds contained in plants have extensive biological functions and have a beneficial effect on a living organism, which determines their use in the technology of flour confectionery and the relevance of their study [5].

The aim of the study is to study the effect of prescription components on the content of antioxidants in flour confectionery products based on flour from light-grain rye grain and vegetable processing products. To achieve this goal, the following tasks were solved:

- study of consumer properties of flour confectionery products;

- investigation of the influence of additives on the nutritional value of flour confectionery products with the addition of vegetable processing products;

- determination of antioxidant activity.

\section{Methods}

The research was carried out: in the educational laboratory for bakery, confectionery and pasta production at the Saratov State Agrarian University named after N.I. Vavilov; in the testing laboratory of food products and food raw materials at ETI (branch) SSTU named after Yu.A. Gagarin; at the Federal State Budgetary Scientific Institution Agrarian Scientific Center of South-East; Voronezh State University of Engineering Technologies.

Experimental options varied in the type of flour and vegetable components in the recipe for flour confectionery products:

1)shortbread cookies Kisher:

- control sample (from wheat flour of the highest grade, without additives);

- sample 2 (from wheat flour of the highest grade, with a dosage of $10 \%$ - carrot powder, $5 \%$ - beetroot powder, with candied fruits from carrots and reducing the proportion of sugar by $10 \%$ );

- sample 3 (from wheat flour of the highest grade, with a dosage of $15 \%$ - carrot powder, $5 \%$ - beetroot powder, with candied fruits from carrots and reducing the proportion of sugar by $20 \%$ );

2) shortbread cookies Kisher made of rye flour:

- control sample (of peeled rye flour, without additives); 
- sample 2 (from light grain rye flour of Solnyshko grade, with a dosage of $20 \%$ - carrot powder, with candied fruits from carrots and a decrease in the proportion of sugar by $20 \%$;

- sample 3 (made from light grain rye flour of Pam. Bambysheva, with a dosage of $20 \%$ - carrot powder, with candied fruits from carrots and a decrease in the proportion of sugar by $20 \%$;

3) custard gingerbread Ball:

- a control sample (from wheat flour of the highest grade);

- sample 2 (from grain flour of light-grain rye of Solnyshko variety with carrot jam);

- sample 3 (from grain flour of light-grain rye variety Pamyati Bambysheva with carrot jam).

For the preparation of jam, vegetable powder and candied fruit, medium-sized carrots were selected, the taste of root vegetables is sweet, without bitterness. Carrot jam was used as a filling in custard gingerbread. To obtain a thermostable filling that does not flow from flour confectionery products, it was decided to dose sodium alginate as a thickener into the recipe in a content of $1 \%$ by weight of all raw materials. Vegetable powder from the root crops of carrots and beets (table) was obtained by artificially drying vegetables using heated air elements at the temperature of $75-80{ }^{\circ} \mathrm{C}$ for 2-3 hours.

Flour from light grain rye, as well as root vegetables of carrots and beetroot have a sweet taste, therefore, we investigated the possibility of reducing the proportion of white sugar in the recipe for Kisher shortbread cookies by 10-20\%, in the recipe for Kisher shortbread cookies made of rye flour - by $20 \%$, in the recipe for custard gingerbread $50 \%$. As a result, products with a reduced carbohydrate content and improved taste properties were obtained [6].

The content of antioxidants in samples is determined by the content of natural flavonoids, namely, catechins (substances of the flavan group); quercetin, rutin, dihydroquercetin (substances of the flavone group); as well as vitamins and other compounds capable of binding free radicals [7].

This technique is based on an amperometric method for determining the content of antioxidants, which consists in measuring the electric current that occurs during the oxidation of the test substance (or mixture of substances) on the surface of the working electrode at a certain potential and comparing the received signal with the signal of the standard (quercetin) measured in the same conditions. Measurements are carried out on the analyzer of antioxidant activity TsvetYauza-01-AA (Fig. 1).

Before measurement, solid samples of flour confectionery products are preliminarily dissolved or subjected to extraction. Next, the liquid sample is filtered through a blue ribbon filter paper and diluted.

The prepared sample shall be drawn into a medical syringe with a capacity of $1 \mathrm{~cm} 3$ and the dosing loop must be rinsed with the dosing valve in the "inlet" position.

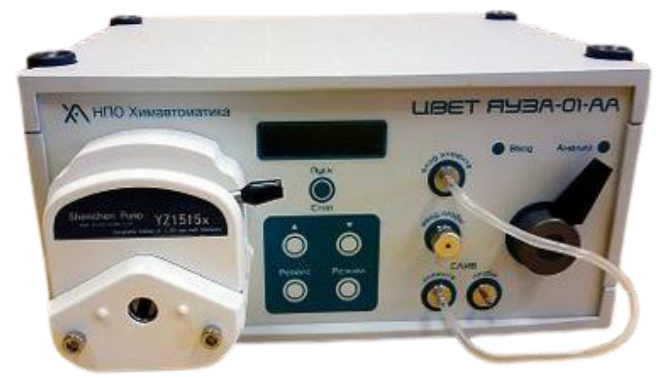

Fig. 1. Analyzer of antioxidant activity TsvetYauza-01-AA. 
Next, the measurement is carried out. The analyzer of antioxidant activity TsvetYauza01-AA works as follows: the pump constantly pumps the eluent, taking it from the container through the entire system. The test solution is injected into the dosing valve in the "inlet" position with a standard medical syringe (capacity $1 \mathrm{~cm} 3$ ) into the dosing loop. The eluent flow directs the dose of the test sample solution by turning the valve knob to the "analysis" position, into the detector cell. In the detector cell on the surface of the working electrode, the molecules of the test sample are oxidized, with an increase in the electric current between the two electrodes. The magnitude of the electric current depends on the nature of the analyzed sample, the nature of the working electrode and the potential that is applied to the electrode [7].

Electric currents that arise during the analysis are very small (within 10-6 - 10-9 A). These analog signals are amplified and then converted into a digital signal that is recorded on the computer display.

The working electrode is made of glassy carbon; it is the most versatile in the determination of polyphenolic compounds. The potential is measured in the range from +2.0 to $-2.0 \mathrm{~V}$; when constructing a calibration graph, set $+1.3 \mathrm{~V}$.

A $2.2 \mathrm{mM}$ solution of H3PO4 was used as an eluent; its feed rate was $1.2 \mathrm{~cm} 3 / \mathrm{min} .5$ parallel measurements of the signals (area of the output curve) of the test solutions are carried out. The arithmetic mean of five measurements is taken as the result (standard deviation is not more than $5 \%$ ).

Calculation of the content of antioxidants $(\mathrm{mg} / \mathrm{dm} 3)$ of the test sample is carried out according to the calibration graph of quercetin. If necessary, the resulting value is converted to $\mathrm{mg} / \mathrm{cm} 3$. When calculating the final result for liquid samples, take into account the dilution of the sample (if any).

The calculation is carried out according to the formula:

$$
\mathrm{CA}=\mathrm{CA}_{\text {gr. }} * \mathrm{~N},(1)
$$

where $\mathrm{CA}_{\text {gr. }}$ - the value of the content of antioxidants, found by the calibration graph, $\mathrm{mg} / \mathrm{dm}^{3}$;

$\mathrm{N}$ is the dilution of the analyzed sample.

In the case of analysis of solid samples, the content of antioxidants $(\mathrm{mg} / \mathrm{g})$ is calculated by the formula:

$$
\mathrm{CA}=\frac{\mathrm{CAгр.} \bullet \text { Vп } \bullet \mathrm{N}}{\mathrm{m}_{\text {пр }} \bullet 1000}
$$

where $\mathrm{CA}_{\text {gr. }}$ - the value of antioxidant activity, found by the calibration graph, $\mathrm{mg} / \mathrm{dm}^{3}$;

$\mathrm{V}_{\mathrm{p} \text {. }}$ - the volume of the solution (extract) of the analyzed sample, $\mathrm{cm}^{3}$;

$\mathrm{m}_{\mathrm{pr}}$ - sample of the analyte, $\mathrm{g}$.

$\mathrm{N}$ is the dilution of the analyzed sample.

When conducting comparative analyzes of samples that do not require special accuracy, it is allowed not to build a calibration graph of quercetin. In this case, the signal of the test sample (the area of the output curve) and the signal of quercetin are measured. The concentration of the quercetin solution is selected so that the signal ratio does not exceed 1.2 [7].

The content of antioxidants $\left(\mathrm{mg} / \mathrm{cm}^{3}\right)$ is calculated by the formula:

$$
\mathrm{CA}=\left(\mathrm{S}_{\mathrm{rev}} / \mathrm{S}_{\mathrm{st}}\right) * \mathrm{C}_{\mathrm{st}},(3)
$$

where $S_{\text {rev }}$ - the area of the output curve of the test sample;

$\mathrm{S}_{\mathrm{st}}$ - the area of the output curve of quercetin;

$\mathrm{C}_{\mathrm{st}}$ - concentration of quercetin solution, $\mathrm{mg} / \mathrm{cm}^{3}$. 
This sudy methodology ensures that measurements of the content of antioxidants in the test sample are performed with an error that does not exceed $5 \%$ in the entire range of measured values with a confidence level of 0.95 .

\section{Results}

A technology has been developed for production of shortbread cookies with addition of vegetable powder from the roots of carrots and beetroot, with candied carrots (STO, RC, TI 00493497-0022016 Shortbread with the addition of Kisher vegetable processing products). The priority of scientific development is confirmed by patent No. 2688767.

In order to save raw materials, the possibility of reducing the sugar content in the cookies recipe was investigated (Fig. 2, 3, 4).

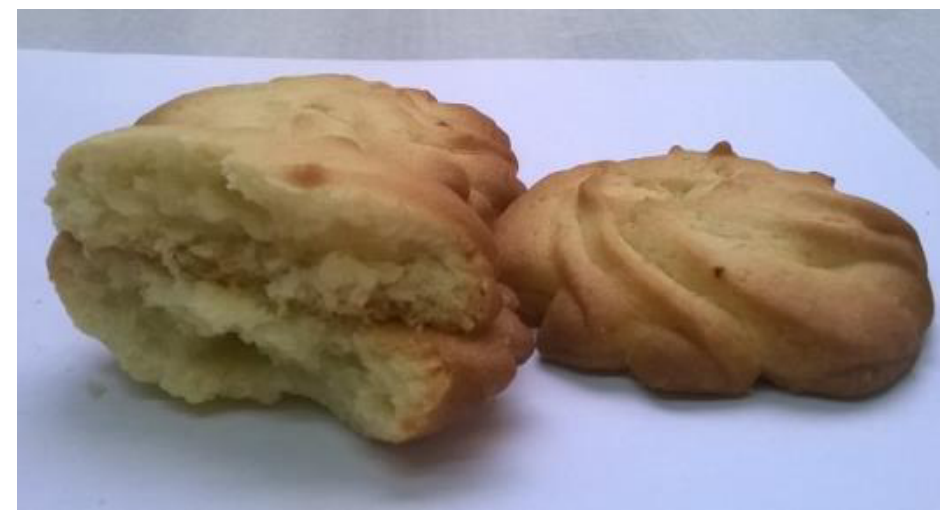

Fig. 2. A control sample (from wheat flour of the highest grade, without additives).

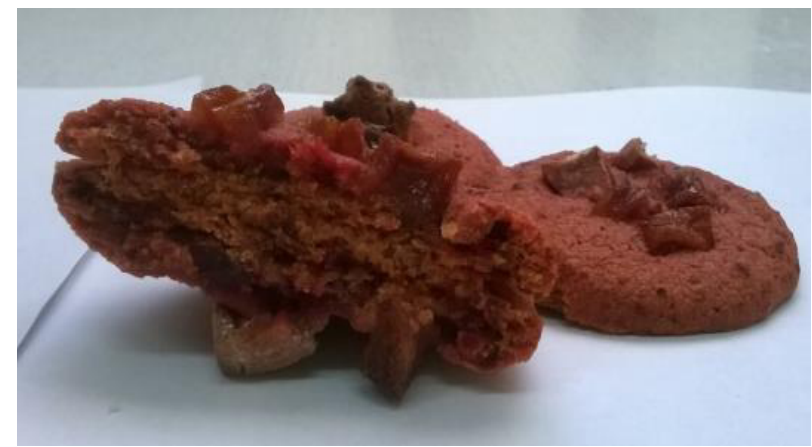

Fig. 3. Sample 2 (from wheat flour of the highest grade, with a dosage of $10 \%$ - carrot powder, $5 \%$ beetroot powder, with candied carrots and a reduction share of sugar by $10 \%$ ). 


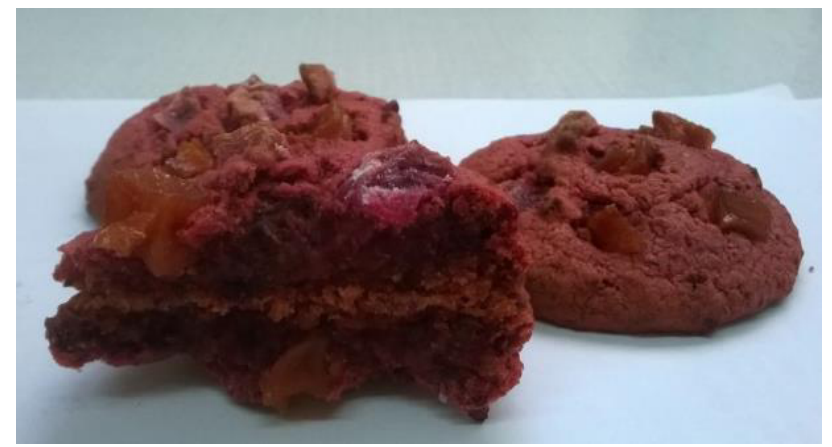

Fig. 4. Sample 3 (from wheat flour of the highest grade, with a dosage of $15 \%$ - carrot powder, $5 \%$ beetroot powder, with candied carrots and a reduction share of sugar by $20 \%$ ).

In order to increase the nutritional value of shortbread cookies, it is advisable to replace wheat flour of the highest grade in the recipe for shortbread cookies Kisher with flour from light grain rye [8], and it was also decided to completely replace vegetable powder from beetroot with vegetable powder from carrots (Figs. 5, 6, 7). The content of white sugar in the recipe for shortbread cookies Kisher made from rye flour was reduced by $20 \%$.

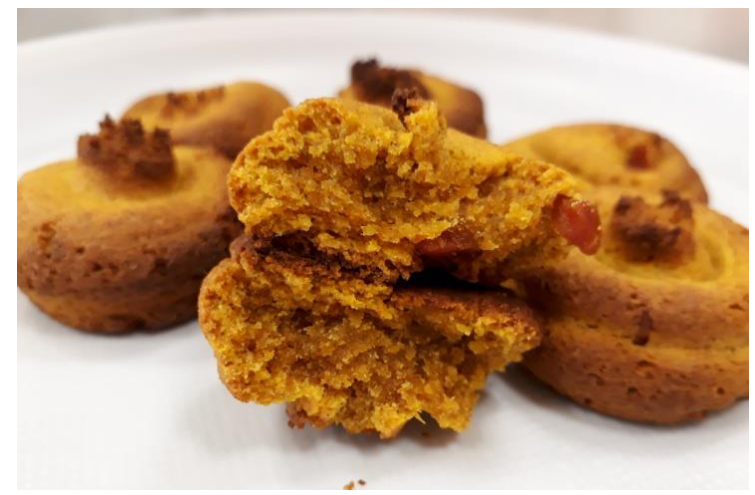

Fig. 5. Influence of the dosage of vegetable powder and white rye flour on finished products: Control sample (from peeled rye flour).

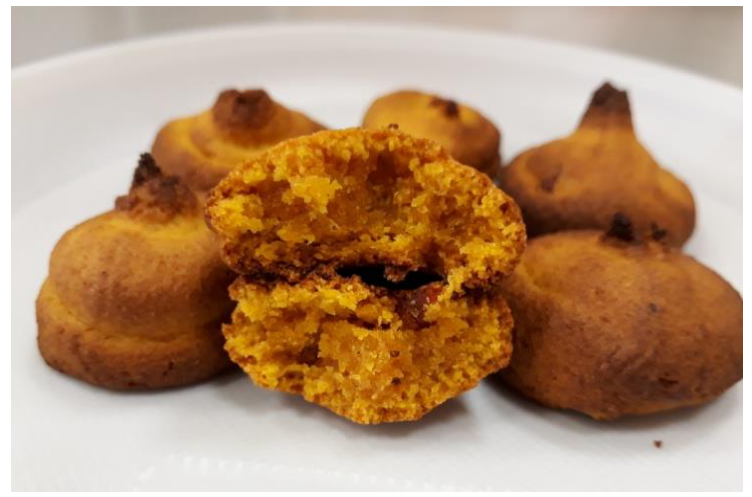

Fig. 6. Influence of the dosage of vegetable powder and white rye flour on finished products: sample 2 (based on flour from light grain rye grain of the Pam. Bambysheva. 


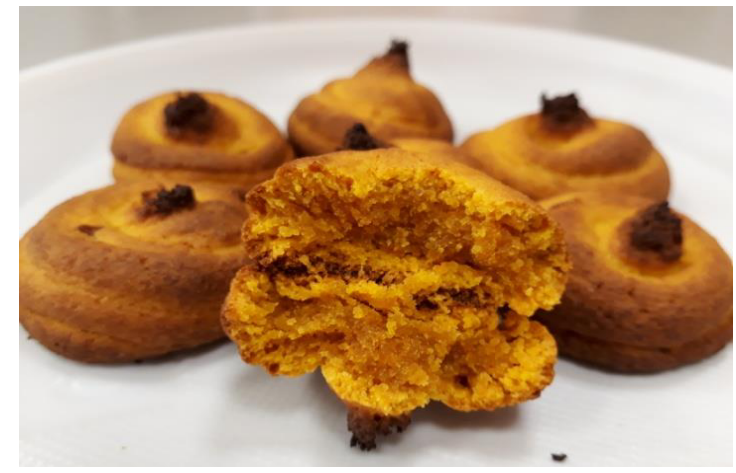

Fig. 7. Influence of the dosage of vegetable powder and flour from white rye on finished products: sample 3 (based on flour from light grain rye grain of Solnyshko variety).

A technology has been developed for making custard gingerbread based on flour from light-grain rye with carrot jam (STO, TI, RC 10.71-006-00493497-2020 Gingerbread product with carrot jam Bal). The priority of scientific development is confirmed by the RF patent No. 2742243. In order to save raw materials and manufacture products with dietary properties, it was decided to reduce the proportion of sugar in the recipe for carrot jam by $50 \%$ Finished products are shown in Figs. $8-10$.

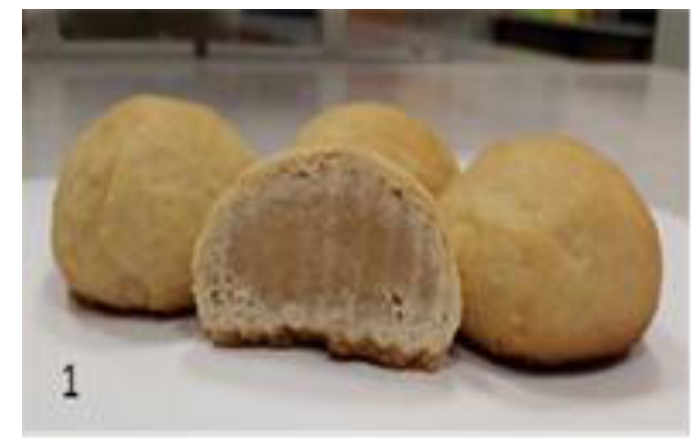

Fig. 8. Custard gingerbread: control sample (made of wheat flour of the highest grade, without additives).

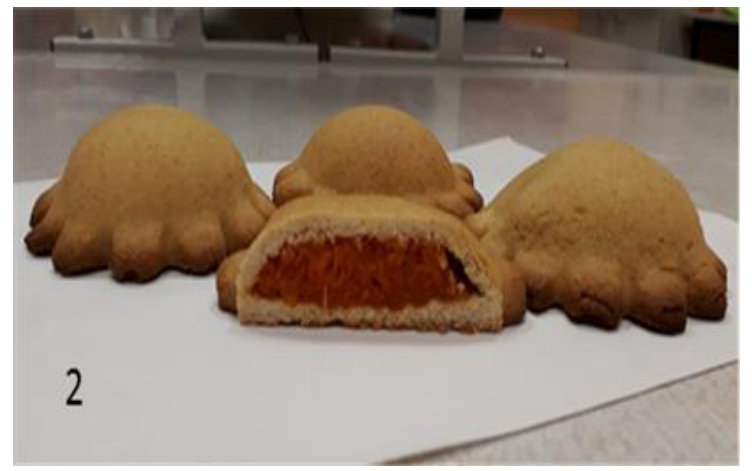

Fig. 9. Custard gingerbread: sample 2 (based on flour from light-grain rye grades Solnyshko with carrot jam). 


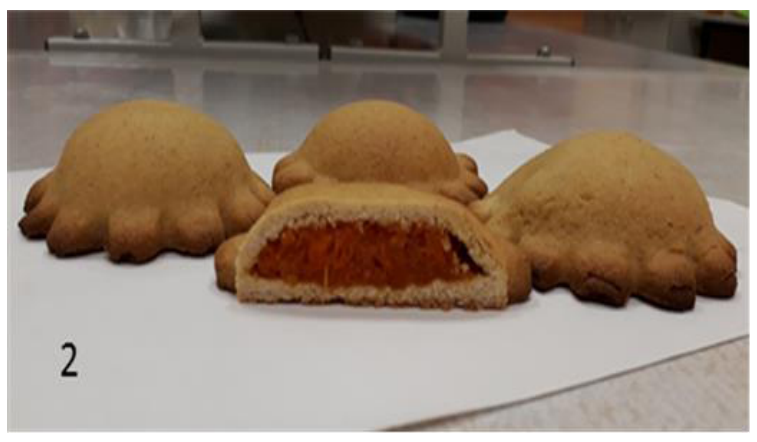

Fig. 10. Custard gingerbread: sample 3 (based on flour from light grain rye grade Pam. Bambysheva with carrot jam).

As a result of introduction of vegetable powder from carrots and beets (table), candied fruits and jam from carrots into the formulation of flour confectionery products, and a decrease in the dosage of sugar, the nutritional value of finished products changes [9]. The content of naturally occurring antioxidants is shown in Table 1.

Table 1. The content of antioxidants of natural origin.

\begin{tabular}{|c|c|c|c|}
\hline \multirow{2}{*}{ Name of nutrients } & \multicolumn{3}{|c|}{ Nutrient content, $\%$ of the norm per $100 \mathrm{~g}$ of the finished product } \\
\hline & Beetroot & Carrot & Light grain rye \\
\hline \multicolumn{4}{|c|}{ Vitamins } \\
\hline Beta carotene & $0.2 \%$ & 240.0 & 0.1 \\
\hline $\mathrm{C}$ & 11.1 & 5.6 & - \\
\hline PP (nicotinic acid) & 2.0 & 5.5 & 21.4 \\
\hline K (phylloquinone) & 0.2 & 11.0 & 4.9 \\
\hline A & 0.2 & 222.2 & - \\
\hline E (alpha-tocopherol) & 0.7 & 2.7 & 8.3 \\
\hline \multicolumn{4}{|c|}{ Macro and microelements } \\
\hline Selenium & 1.3 & 0.2 & 30.5 \\
\hline Zinc & 3.5 & 3.3 & 19.5 \\
\hline Sulfur & 0.7 & 0.6 & 8.5 \\
\hline
\end{tabular}

Determination of the content of antioxidants was carried out according to the method described above. Electric currents that arise during the analysis are converted into a digital signal, which is recorded on the computer display, as a result of which the construction of chromatograms is carried out (Fig. 11-19). 


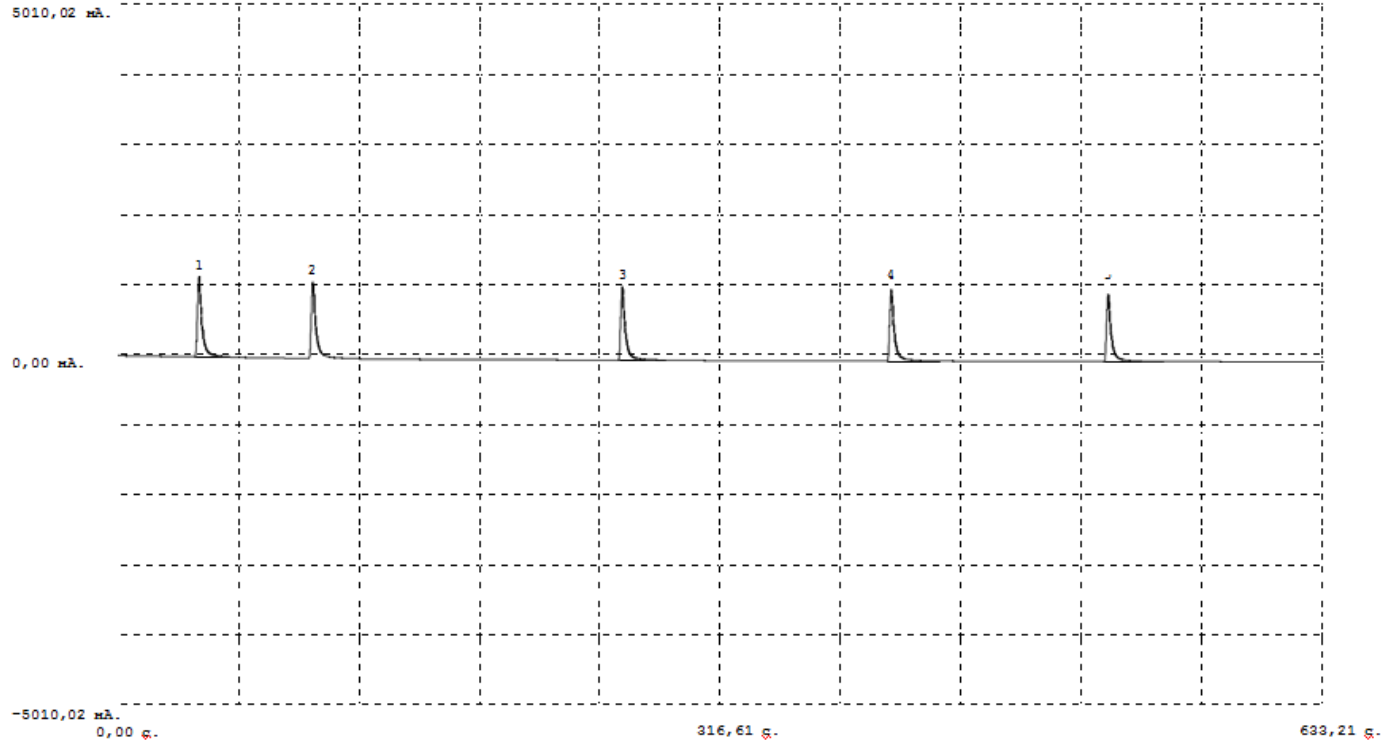

Fig. 11. Chramotogram of shortbread cookies Kisher: control sample (of wheat flour of the highest grade, without additives).

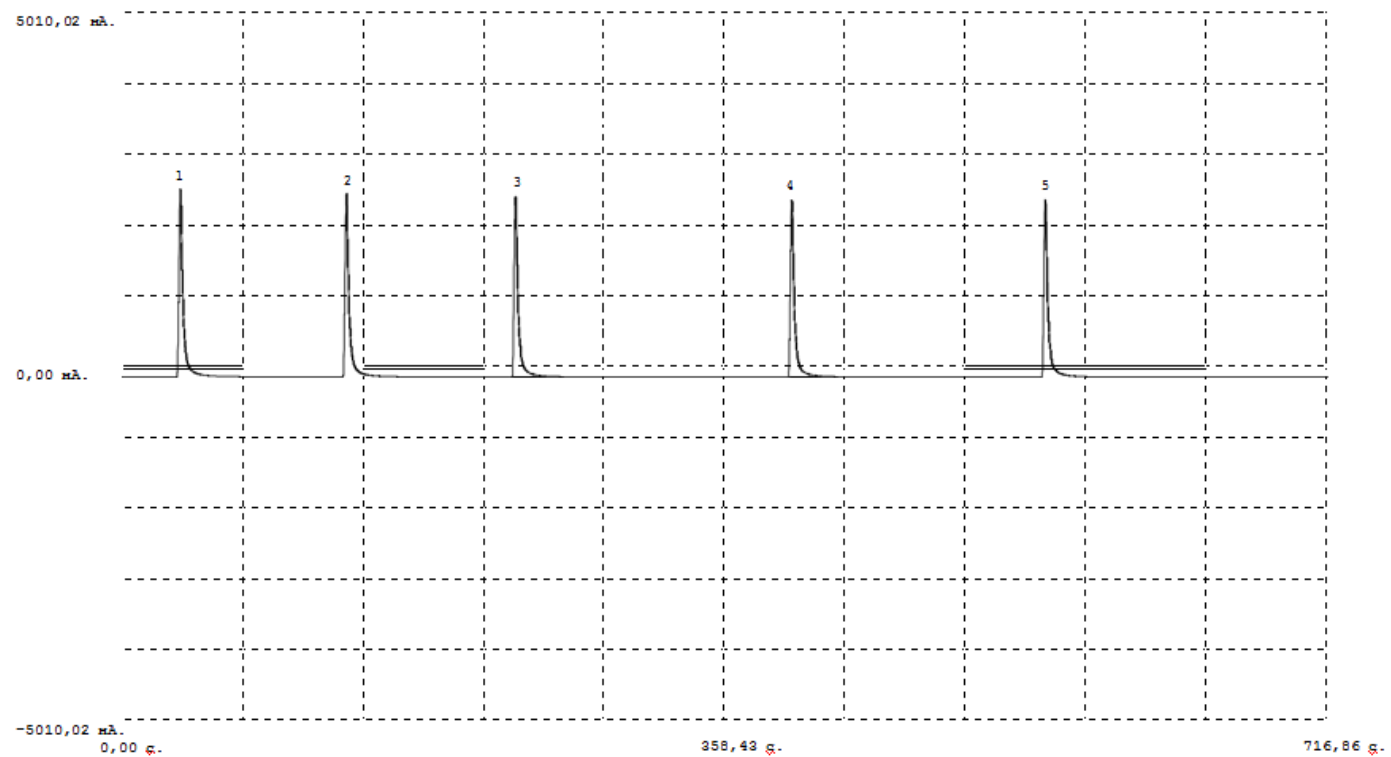

Fig. 12. Chramotogram of shortbread cookies Kisher: sample 2 (from wheat flour of the highest grade, with a dosage of $10 \%$ - carrot powder, $5 \%$ - beetroot powder, with candied carrots and reducing the proportion of sugar by $10 \%$ ). 


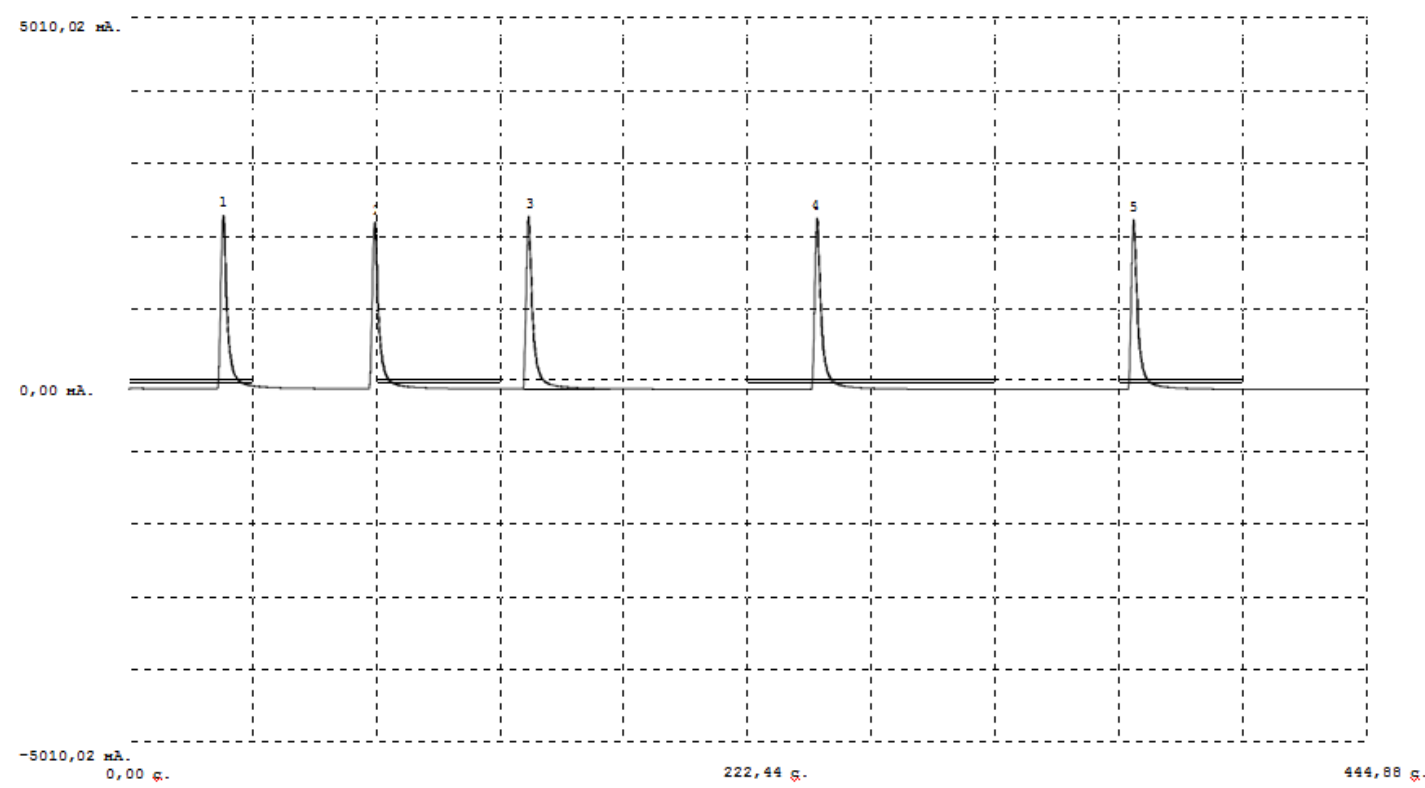

Fig. 13. Chramotogram of shortbread cookies Kisher: sample 3 (of wheat bakery flour of the highest grade, with a dosage of $15 \%$ - carrot powder, $5 \%$ - beetroot powder, with candied carrots and reducing the proportion of sugar by $20 \%$ ).

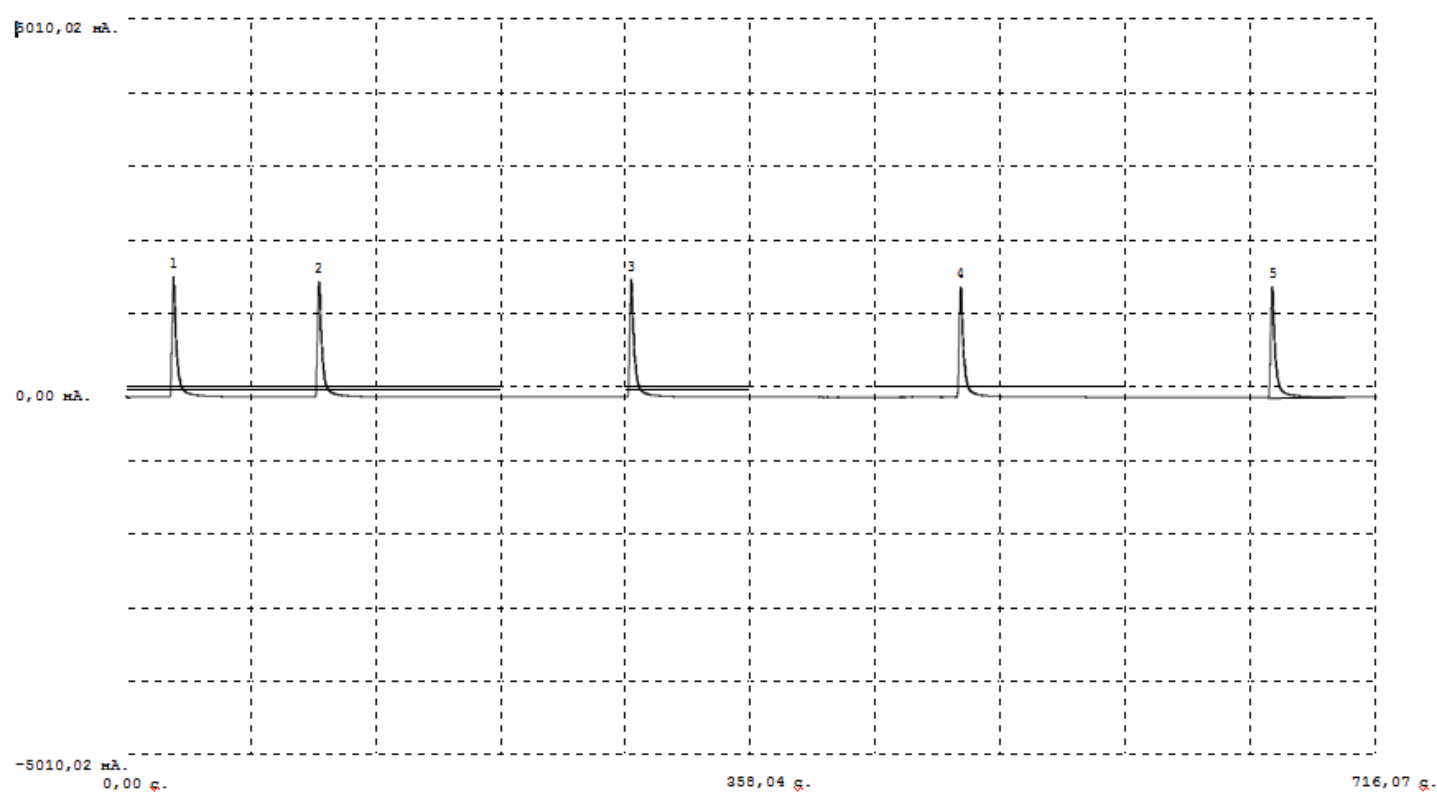

Fig. 14. Chramotogram of shortbread cookies Kisher of rye flour varieties: control sample (from peeled rye flour). 


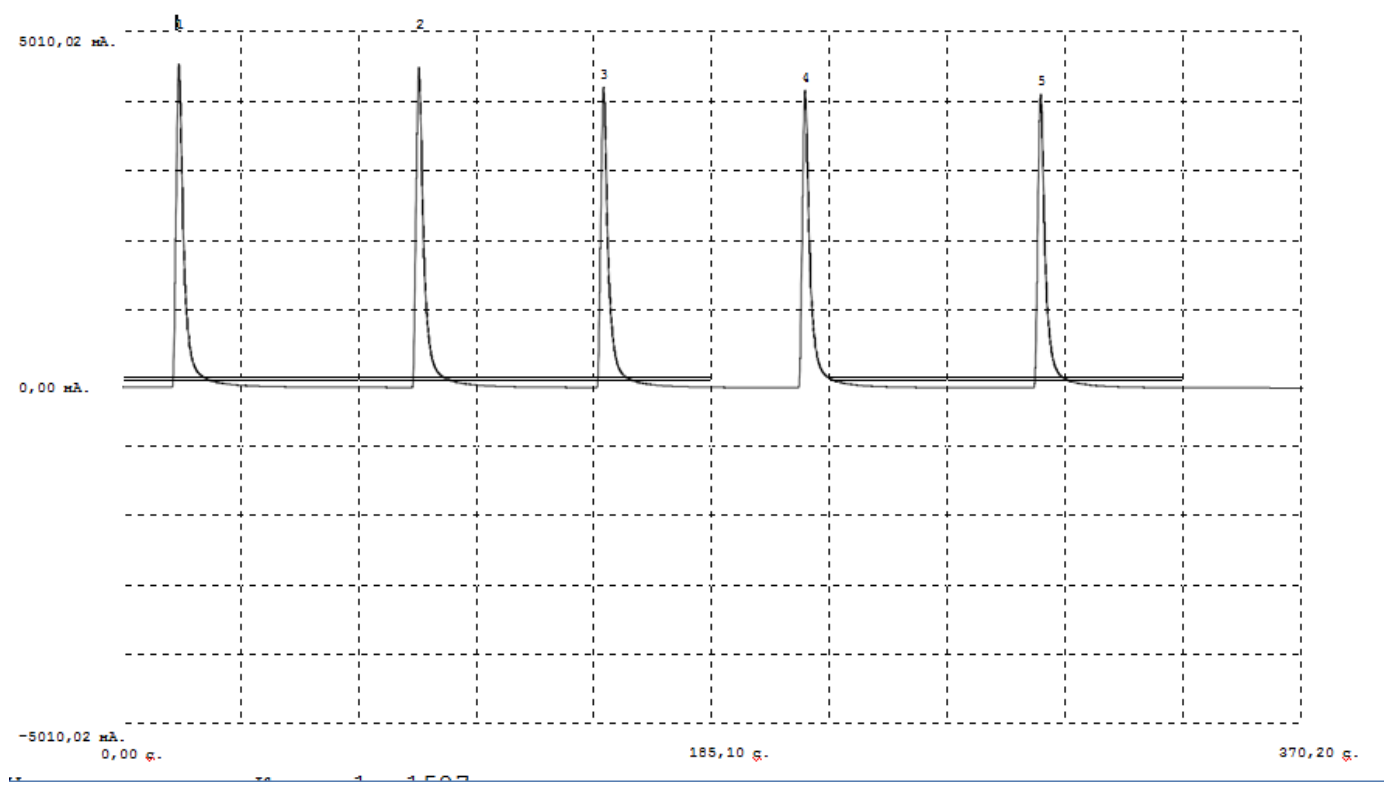

Fig. 15. Chramotogram of shortbread cookies Kisher made of flour of rye varieties: sample 2 (on the basis of flour from grain of light-grain rye varieties Solnyshko).

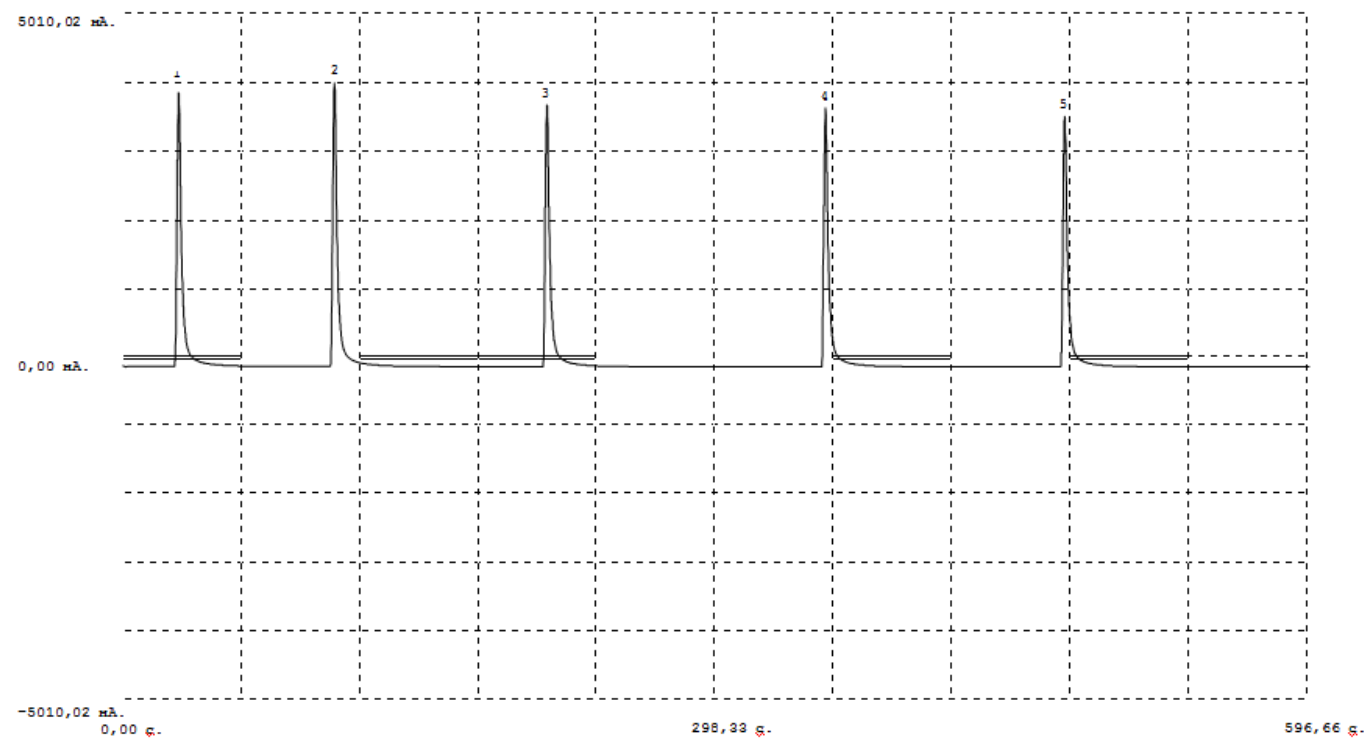

Fig. 16. Chramotogram of shortbread cookies Kisher made of rye flour varieties: sample 3 (based on flour made from light-grain rye grain of the Pam. Bambysheva). 


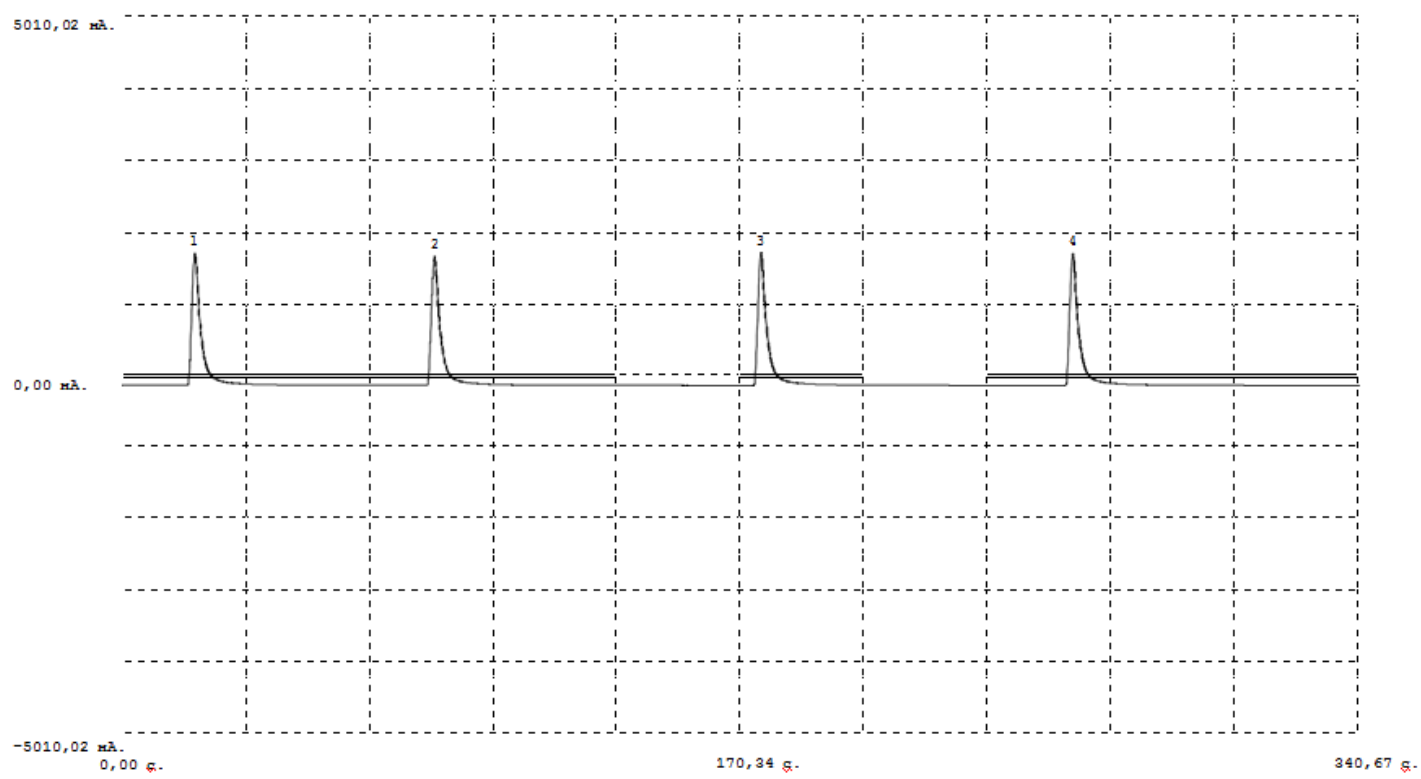

Fig. 17. Chramotogram of custard gingerbread: control sample (from wheat flour of the highest grade, without additives.

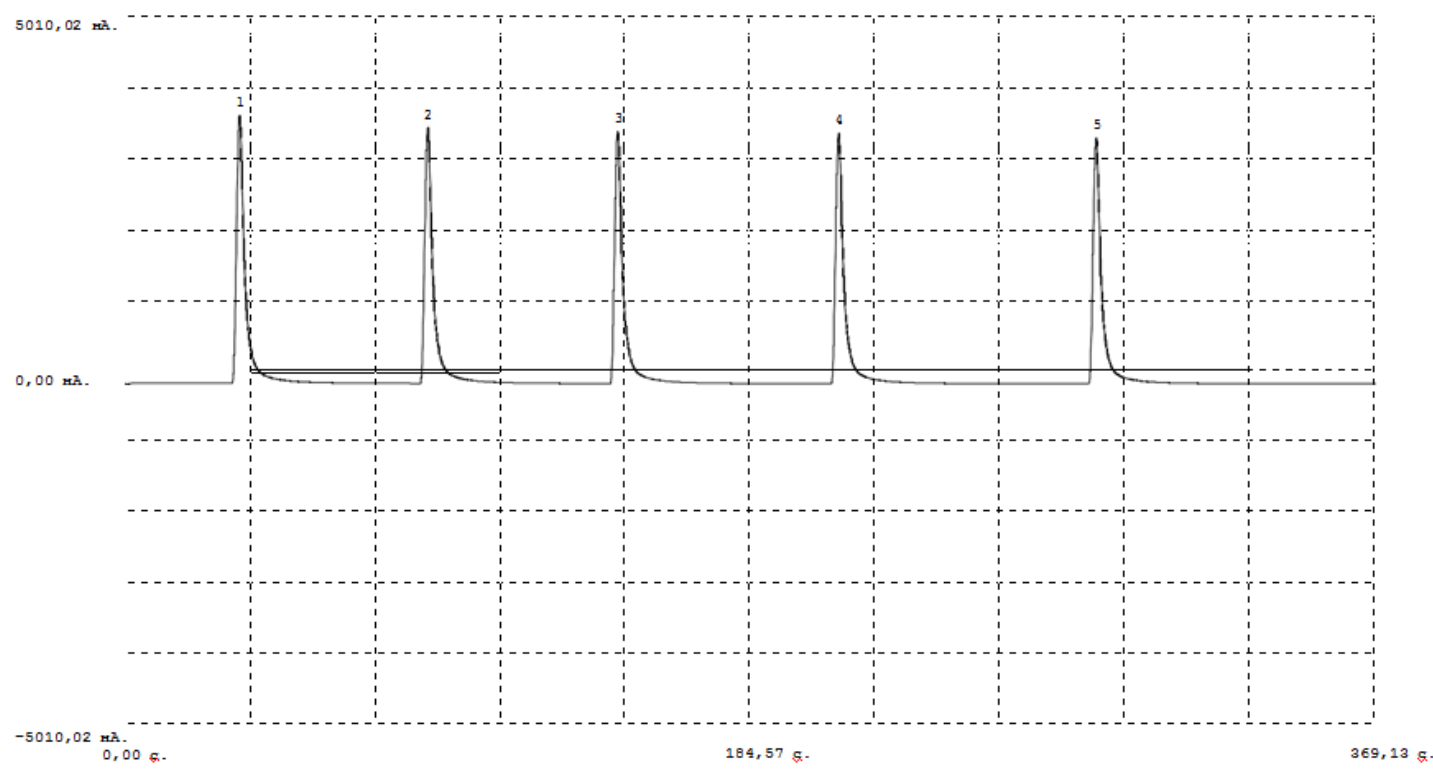

Fig. 18. Chramotogram of custard gingerbread: sample 2 (based on flour made of grain of light-grain rye of Solnyshko variety with carrot jam). 


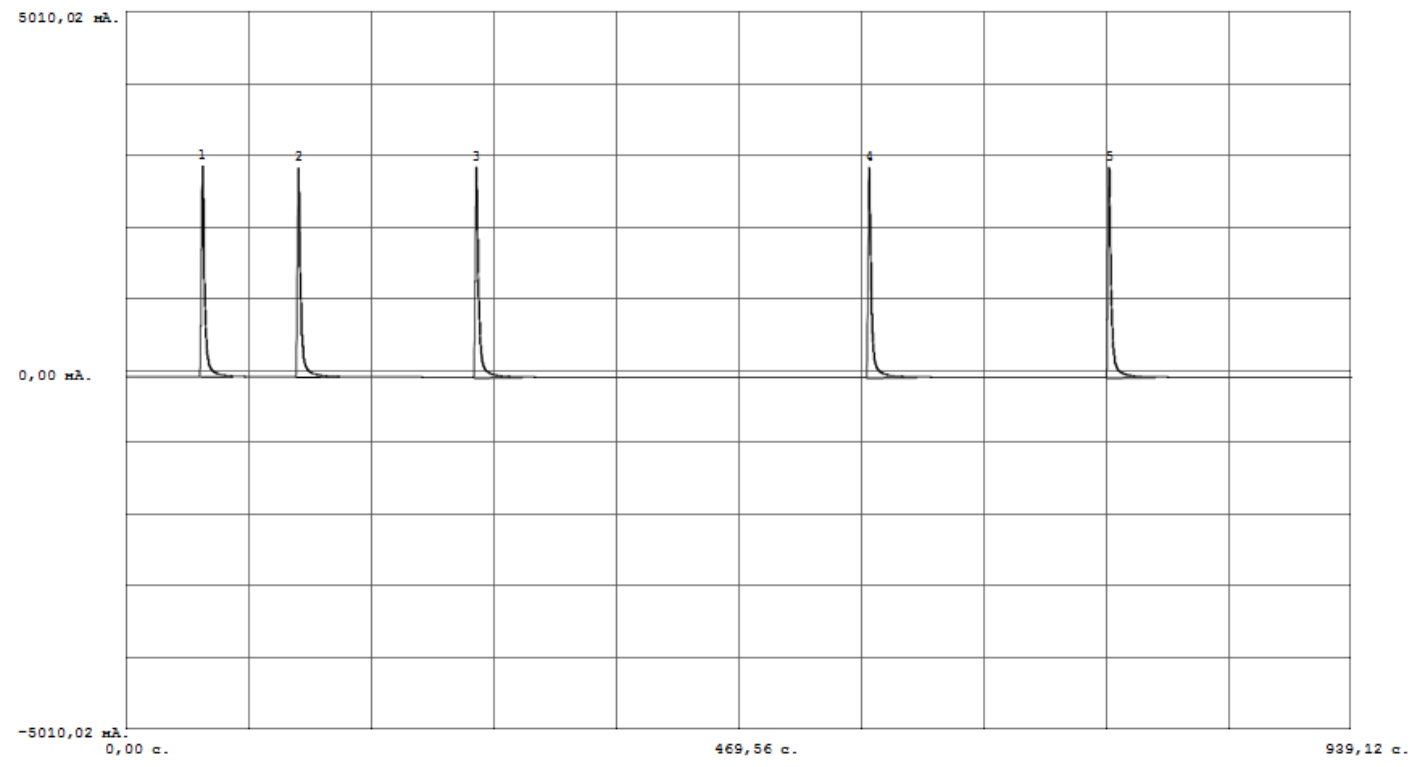

Fig. 19. Chramotogram of custard gingerbread: sample 3 (based on flour of light grain rye grades Pam. Bambysheva with carrot jam).

Five parallel measurements of the signals of the area of the output curve of the test samples are carried out. The arithmetic mean of five measurements is taken as the result (standard deviation is not more than $5 \%$ ). Antioxidant contents are calculated using the formula above and the results are reported in Table 2.

Table 2. Antioxidant content (AC).

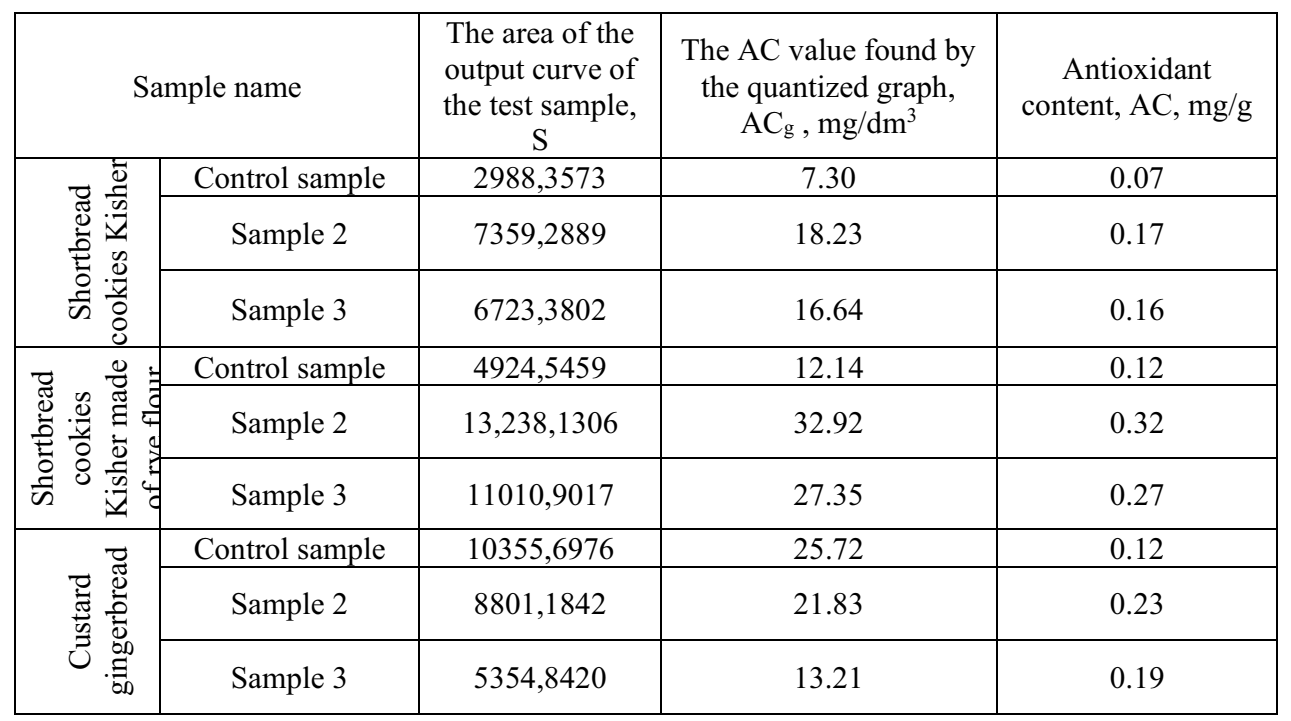




\section{Discussion}

The effect of vegetable powder of carrot and beetroot roots on the quality of Kisher shortbread cookies has been established (Fig. 2): the color of the finished product becomes more intense with an increase in the amount of vegetable powder, in comparison with the sample prepared in accordance with GOST 24901-89 without additional introduction of vegetable powder. Sample 2 - the appearance in the fracture acquires an attractive orange color, whereas with an increase in the additive up to $20 \%$ (sample 3), the appearance in the fracture becomes a darker color, unattractive to consumers. The baked products were characterized by improved taste and aroma. The deterioration of the taste in sample 3 is worth noting. Reducing sugar in the recipe for the cookie sample 3 to $20 \%$ is not desirable, because there is an aftertaste of vegetable powders obtained from root crops [10].

The structure of the cookies also changes, friability increases. As a result of a comprehensive assessment of the quality of the finished product, an option stands out with the content of vegetable powders in the ratio of $10 \%$ - carrot and $5 \%$ - beetroot and a $10 \%$ reduced sugar content in the recipe for shortbread cookies, which was appreciated by the tasters.

For shortbread cookies Kisher made of rye flour (Fig. 3), according to organoleptic characteristics, shortbread cookies made from light grain rye flour of Solnyshko variety are considered the best. The product has a delicate milky taste that is pleasant to the consumer. The recipe also includes $20 \%$ of vegetable powder of carrots and candied fruit from carrots in an amount of $10 \%$. Flour of light grain rye can reduce the sugar content in the recipe for shortbread cookies by $20 \%$, which gives the product dietary properties and increases economic efficiency. The baked products were characterized by improved taste and aroma.

In custard gingerbread based on flour made from light-grain rye with carrot jam (Fig. 4), in comparison with the control sample, the appearance in the fracture is attractive to consumers, the filling is inside the product, does not flow out onto the surface of the product. The taste and aroma are pronounced, sweet, with a taste of carrots. The structure of the gingerbread is in all cases soft, tied, does not crumble when broken. As a result of the tasting assessment of the quality of the finished product, an option is distinguished based on flour made from light grain rye of Solnyshko variety with carrot jam [11].

The dosage of flour of light-grain rye grain and vegetable processing products provides flour confectionery products with substances that are antioxidants of natural origin (Table 1). Water-soluble vitamins $C$ and $P$ strengthen the cardiovascular system, ensure the body's resistance to infections, bacteria and other unfavorable environmental factors. Fat-soluble vitamins: A, E, K, beta-carotene improve visual acuity, maintain healthy mucous membranes, rejuvenate skin and improve hair condition. The minerals selenium, sulfur and zinc support the normal functioning of the immune system and metabolism, protect the body from the effects of heavy metals, and participate in the process of cell regeneration [12].

From the data provided in table 2, it follows that the content of antioxidants in samples of shortbread cookies Kisher from wheat flour of the highest grade, with a dosage of $10 \%$ carrot powder, $5 \%$ - beetroot powder, with candied fruits from carrots and a decrease in the proportion of sugar by $10 \%$ more than in the control sample by 2.4 times, in sample 3 (from wheat flour of the highest grade, with a dosage of $15 \%$ - carrot powder, $5 \%$ beetroot powder, with candied carrots and a decrease in the proportion of sugar by $20 \%$ ) 2.3 times. An increase in this quality indicator is also observed in shortbread cookies Kisher made of rye flour: in sample 2 (based on flour made of light-grain rye of Solnyshko variety), it increases 2.7 times, in sample 3 (based on flour of light-grain rye variety Pam. Bambysheva) - 2.3 times, compared with the control sample made of peeled rye flour. If we compare the performance of Kisher shortbread cookies and Kisher shortbread cookies made 
of rye flour, we can see a significant increase in the content of antioxidants by 1.2-1.8 times, which was achieved by replacing premium wheat flour with rye flour.

In custard gingerbread, an increase in the content of antioxidants is observed in sample 2 (based on flour of light-grain rye of Solnyshko variety with carrot jam) - 1.9 times, and in sample 3 (based on flour of light-grain rye varieties Pamyati Bambysheva with carrot jam) 1.6 times as compared to the control sample. This testifies to the beneficial effect of lightgrain rye flour and carrot jam on the antioxidant activity of flour confectionery products.

Therefore, the production of flour confectionery products based on flour of light grain rye with the addition of vegetable processing products will allow the production of competitive products, since use of this raw material expands the range of products of therapeutic and prophylactic action. The plant components introduced into the formulation of flour confectionery products increase the content of antioxidants, which allow to increase the shelf life of finished products and contribute to an increase in the antioxidant status of the body.

\section{Conclusion}

In the course of the work, jam of carrot roots, vegetable powders from carrots and table beets, as well as candied fruits from carrots were obtained.

The organoleptic indicators of the quality of flour confectionery were studied. It has been established that use of flour made of light grain rye and processed vegetable products has a positive effect on the quality of shortbread cookies and custard gingerbread. Products acquire an attractive and fractured appearance. Table sugar contained in light-grain rye and root crops of carrots and beets makes it possible to reduce the content of white sugar in the formulation of flour confectionery products, which gives the products dietary properties, here the name is given to resource-saving technology.

In experimental samples of flour confectionery products based on wheat flour with vegetable processing products, the content of antioxidants increases 2.4 times, compared with the control sample. Whereas in experimental samples of flour confectionery products based on flour from light grain rye, the content of antioxidants increases 3-4 times, compared with the control sample from wheat flour. However, when comparing control samples in a sample based on flour of the grain of light grain rye variety Solnyshko, the content of antioxidants is 1.8 times higher, in contrast to the sample from wheat flour.

Therefore, the production of flour confectionery products based on flour of light grain rye with the addition of vegetable processing products will allow the production of competitive products, since use of this raw material expands the range of products of therapeutic and prophylactic action. The plant components introduced into the formulation of flour confectionery products increase the content of antioxidants, which make it possible to increase the shelf life of finished products and contribute to an increase in the antioxidant status of the body.

\section{References}

1. N.N. Kornen, M.V. Lukyanenko, T.A. Shahray, Nauchnyj zhurnal KubGAU, 126, 2 (2017)

2. M.A. Kuhn, The American Journal of Nursing, 103, 4 (2003)

3. M.M. Bakuev, K.K. Magomedov, R.K. SHahbanov, M.A. Magomedov, Nauchnyj zhurnal FGBOU VO DGMU Minzdrava Rossii (2012)

4. T.N. Tertychnaya, N.N. Fonina, E.Y. Manukovskaya, V.I. Orobinsky, I.V. Mazhulina, Bread products, 9 (2014) 
5. A.A. Itunkaya, Irish Journal of Agricultural and Food Research, 53, 2 (2014)

6. T.Ya. Ermolaeva, N.N. Nuzhdina, L.V. Andreevs, Materials of the VII International scientific and practical conference «Technologies and Products of Healthy Food» (Saratov, 2013)

7. Metodika vypolneniya izmerenij soderzhaniya antioksidantov v napitkah i pishchevyh produktah, biologicheski aktivnyh dobavkah, ekstraktah lekarstvennyh rastenij amperometricheskim metodom (MVI 31-07, 2002)

8. T.B. Kulevatova, D.V. Kajrgaliev, L.V. Andreeva, T.YA. Ermolaeva, L.N. Zlobina, N.N. Nuzhdina (Saratov, OOO «RAKURS», 2016)

9. V.A. Tutel'yan, Himicheskij sostav i kalorijnost' rossijskih pishchevyh produktov (Moskva, DeLi plyus, 2012)

10. A.R. Tugush, M.K. Sadygova, Agrarnyj nauchnyj zhurnal, 1 (2018)

11. A.R. Tugush, M. K. Sadygova, T. I. Anikienko, M. V. Belova, A.V. Kondrashova, Z.I. Ivanova, Sbornik statej Mezhdunarodnoj konferencii po proizvodstvu i pererabotke sel'skohozyajstvennogo syr'ya, 640, 2 (2020)

12. A.K. Tiwari, Current Science, 81, 9 (2001) 